\title{
Processing of Yam Paste (Amala): A Product of Fermented Yam (Dioscorea rotundata) Flour
}

\author{
Anthony Okhonlaye Ojokoh ${ }^{1}$, Bartholomew Saanu Adeleke² \\ ${ }^{1}$ Department of Microbiology, Federal University of Technology, P.M.B. 704, Akure, Nigeria \\ ${ }^{2}$ Department of Biological Sciences, Ondo State University of Science and Technology, \\ P.M.B. 353, Okitipupa, Nigeria
}

* Corresponding author email: microbade@yahoo.com

Received: 24 May 2019 / Revised: 03 October 2019 / Accepted: 22 October 2019 / Published: 27 October 2019

\begin{abstract}
This study was designed to evaluate the processing of yam paste (amala): A product of fermented yam (Discorea rotundata) flour. The sliced yam samples were fermented for 72 hours. The microorganisms were isolated and identified. The $\mathrm{pH}$, TTA, temperature, proximate, anti-nutrient, mineral composition and sensory analyses of the sample were determined. The microbial loads increased with fermentation time. The isolates identified were Pseudomonas aureginosa, Staphylococcus aureus, Bacillus subtilis, Lactobacillus plantarum, Lactococcus lactis, Aspergillus niger, Saccharomyces cerevisiae, Fusarium oxysporium, and Candida tropicalis. pH decreased from 6.4 to 4.9 while TTA and temperature increased from 0.16 to $4.24 \%$ and $28^{\circ} \mathrm{C}$ to $34^{\circ} \mathrm{C}$. The crude protein $(2.46 \%)$ and moisture contents $(12.32 \%)$ increased in the fermented sample with a decrease in ash $(0.70 \%)$, fat $(0.19 \%)$ and carbohydrate contents $(80.76 \%)$. The saponin and phytate decreased from 31.29 to $11.45 \mathrm{mg} / \mathrm{g}$ and 11.12 to $5.77 \mathrm{mg} / \mathrm{g}$. The fermented sample showed an overall acceptability. Improvement in the nutritional and reduction in antinutritional contents of the fermented sample suggests its usefulness as a food source for humans. The microorganisms associated with fermented yam tubers, processing of yam tubers into flour to produce amala and determining the nutritional and antinutrient content of both unfermented and fermented yam. The fermentation process improving the quality and nutrient content of the yam tubers suggested the method as more promising in producing food for humans.
\end{abstract}

Keywords: Fermented foods, proximate composition, sensory evaluation, yam tubers, yam paste (amala).

\section{Introduction}

Globally, roots and tuber crops are very important in ensuring food security in most countries. Some examples of these include sweet potato, yam, cocoyam, cassava etc. Yam is a tuberous crop grown in many countries of the world [1]. It forms bulk of staple foods in many homes most especially in Nigeria. It is ranked fourth most consumed root crops after cassava, potatoes and sweet potatoes in the Sub-Saharan region, especially in West Africa [2]. Yams are grown in an area with optimum rainfall in the Southern savannah region. Yam, a starchy edible food is most important in the socio-economic and cultural activities in Sub-Saharan Africa like Nigeria and Ghana during marriage and fertility ceremonies [3]. Yam contains high amount of energy, starch, dietary fibre, calcium, phosphorous, magnesium, selenium, zinc, betacarotene, manganese, riboflavin, ascorbic acid and thiamine. It is rich in phenyalanine and threonine but limiting in the sulphur amino-acids (cysteine and methionine) and tryptophan [4]. Yam can be processed into various products such as flour, starch, alcohol, cakes, chips, cookies and lactic acid by boiling, pounding, roasting, and frying using fermentation technology. Fermentation process helps in improving nutritional contents, reduction of antinutrient content, extend shelf life and enhance sensory properties of food products [5]. Yam can be eaten with other food products (beans, stew and leafy vegetables) as delicacy. In Nigeria, Benue State is ranked highest as major producer of yam [6]. 
Despite the uses of yam and yam products, fresh yam tubers are easily perishable after postharvesting due to microbial infestation, injuries by cutting, high moisture content, inadequate preservation, storage and processing facilities, marketing and market access resulting in huge loss of the farm produce; and to minimize this, adequate processing by fermentation and drying are required. Various yam products can be produced through harvesting, transporting, peeling, washing, slicing, blanching, steeping and sun-drying [7]. Yam products can be reconstituted in boiling water to form thick paste which is consumed as meals in the tropics as source of carbohydrates [8]. Fermented yam flour called elubo among Yoruba's, is a product made from yam tubers by stirring in boiling water to make a thick paste known as amala, which is usually eaten with a vegetable stew [9].

Contamination of food products can occur via different channels. The contaminants can be from air, processing utensils, soil, handlers etc which can easily get into the products during or after processing. Post-contamination can occur when the food get in contact with the pollutants during transporting, storage or when the food item is exposed to dust, insects and fugal attack. Different contaminants can be present in yam products such as organic pollutants and mycotoxins. Contamination of foods with mycotoxins poses serious threats to consumer's health which can lead to death [10]. Microbial contamination on food products can be controlled through proper storage, processing techniques and quality control check. Therefore, this research is designed to assess the nutritional and antinutritional contents of fermented yam (Dioscorea rotundata) tubers for the production of yam paste (elubo) for human use.

\section{Materials and Methods}

\subsection{Sample Collection and Preparation}

Healthy yam tubers were purchased from OjaOba market in Akure, Nigeria and then transported to Microbiology laboratory, Federal University of Technology, Akure (FUTA), Nigeria. Two kilogrammes $(2.0 \mathrm{~kg})$ of the yam tubers were weighed, peeled, washed, sliced into small pieces (about $2.0 \mathrm{~mm}$ thickness) and then fermented for 72 hours at room temperature $\left(28^{\circ} \mathrm{C}\right)$. For microbial isolation, $1.0 \mathrm{ml}$ of the fermenting substrate was pipetted and serially diluted into each test tubes containing $9.0 \mathrm{ml}$ sterile distilled water. From the diluents, $0.1 \mathrm{ml}$ pippetted and inoculated into Petri dishes prior pour plating with appropriate sterilized molten agar. The plates were incubated at $37^{\circ} \mathrm{C}$ for 24 hours for bacteria, $27^{\circ} \mathrm{C}$ for $24-36$ hours for lactic acid bacteria and $28^{\circ} \mathrm{C}$ for 48 hours for fungi isolation respectively. After incubation, the distinct colonies formed were counted and recorded. Pure culture of the isolates was obtained by repeated streaking on the fresh media. The microorganisms were identified by various morphological, biochemical, cultural and microscopy characteristics. Both the fermented and the unfermented samples were sun dried and milled separately using Attrition mill and sieved with a 500 micrometer sieve to obtain fine yam flour. The fermentation of yam tubers for yam flour (elubo) production and further processing into yam paste (amala) is represented (Figure 1).

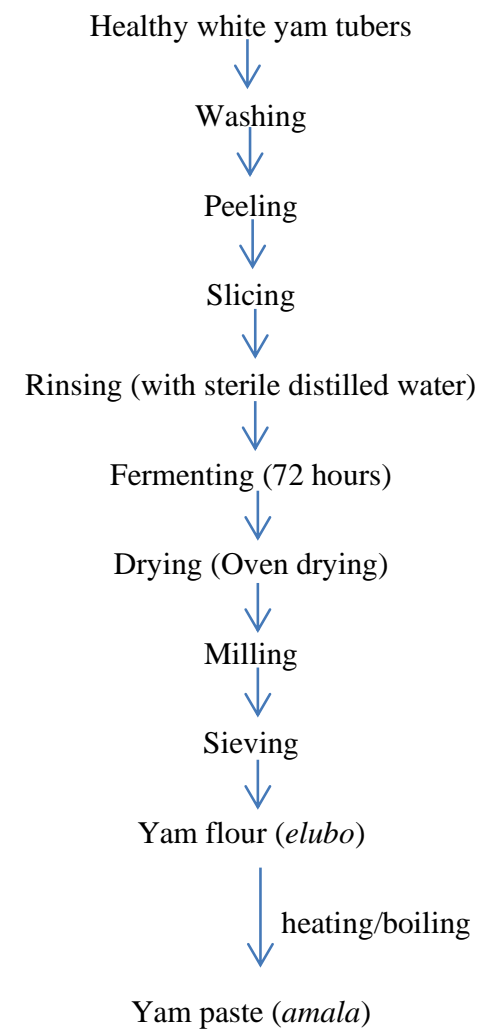

Figure 1: Schematic diagram for the production steps offermented yam flour (elubo) 


\subsection{Determination of $\mathrm{pH}$, Total Titratable Acidity and Temperature}

The $\mathrm{pH}$ of the fermenting sample was measured daily throughout the fermentation process using pH meter (Hanna multi - parameter - H1-9828). The process was carried out by dipping a sterile thermometer into the fermentation medium. The $\mathrm{pH}$ meter was standardizing in a buffer solution at $\mathrm{pH} 7.0$ and 4.0. Total titratable acidity was carried out by weighing $3.0 \mathrm{~g}$ of the fermenting sample, macerated, dispensed into $30 \mathrm{ml}$ sterile distilled water and then filtered. Twenty millilitres $(20 \mathrm{ml})$ of the filtrate was dispensed into a $50 \mathrm{ml}$ conical flask with the addition of 2 drops of phenolphthalein as indicator. The content of the flask was thoroughly mixed and titrated against $0.1 \mathrm{M} \mathrm{NaOH}$. The appearance of a pink colour marked the end point of the reaction. The temperature was measured using thermometer on daily basis.

\subsection{Determination of Proximate and Antinutrients Contents of Fermented Yam Tubers}

Proximate and antinutrient contents of the raw and fermented sample were carried out according to AOAC [11]. The proximate contents monitored were moisture, ash, fat, crude fibre, protein and carbohydrate while the antinutrients content analyzed were phytates, oxalate, saponin and alkaloid.

\subsection{Sensory Evaluation}

The sensory parameters of the processed yam flour (amala) was carried out by trained panellists in the Department of Microbiology, FUTA using 9 hedonic scales ranging from like extremely to dislike extremely. The sensory parameters evaluated were the aroma, colour, taste and texture.

\subsection{Data Analysis}

All analyses were carried out in triplicates. The data obtained were analyzed using analysis of variance (ANOVA) and the difference between the means was separated by Duncan's Multiple Range Test (DMRT) using SPSS software (version 16.0 for Windows, SPSS Inc., Chicago, USA) at $\mathrm{p}<0.05$.

\section{Results}

\subsection{Total Microbial Counts from Fermented Yam Tubers}

Table 1 shows the total microbial counts from fermented yam tubers. The microbial loads increased as the fermentation time progresses. The bacterial counts increased from 85.0 to 215.0. The moulds and yeasts had no growth at the initial stage of the fermentation. The highest bacterial counts 7.0 were obtained at 72 hours while the yeast counts at 24 hours increased from 5.0 to 13.0 .

Table 1: Total Microbial Counts from Fermented Yam Tubers

\begin{tabular}{|l|l|c|c|}
\hline $\begin{array}{l}\text { Time } \\
(\text { hours })\end{array}$ & $\begin{array}{l}\text { Bacterial } \\
\text { counts } \\
(\mathrm{cfu} / \mathrm{ml})\end{array}$ & $\begin{array}{c}\text { Moulds } \\
(\mathrm{sfu} / \mathrm{g})\end{array}$ & $\begin{array}{c}\text { Yeasts } \\
(\mathrm{cfu} / \mathrm{g})\end{array}$ \\
\hline 0 & $85 \times 10^{5}$ & Nil & Nil \\
\hline 24 & $110 \times 10^{5}$ & Nil & $5 \times 10^{3}$ \\
\hline 48 & $160 \times 10^{5}$ & $4 \times 102$ & $8 \times 10^{3}$ \\
\hline 72 & $215 \times 10^{5}$ & $7 \times 102$ & $13 \times 10^{3}$ \\
\hline
\end{tabular}

\subsection{Morphological, Biochemical Characteristics, Cultural and Microscopy Identification of Isolated Microorganisms}

Tables 2, 3 and 4 show the morphological, biochemical characteristics, cultural and microscopy identification of isolated microorganisms from fermented yam tubers. The identified microorganisms were Lactobacillus plantarum, Lactococcus lactis, Klebsiella oxytoca, Citrobacter freundii, Bacillus subtilis, Saccharomyces cerevisiae, Aspergillus niger, Fusarium oxysporum and Candida tropicalis. Lactobacillus plantarum and Lactococcus lactis occurred throughout the fermentation process. Klebsiella oxytoca and Citrobacter fruendii were isolated at 0 hour and 24 hours of the fermentation while Bacillus subtilis and Saccharomyces cerevisiae were isolated at 24, 48 and 72 hours. Aspergillusniger was only isolated at 48 hours. Fusarium oxysporum was isolated at 48 and 72 hours while Candida tropicalis was isolated at 24, 48 and 72 hours respectively (Table 5). 
Table 2: Morphological, biochemical characteristics, cultural ad microscopy identification of isolated microorganisms

\begin{tabular}{|c|c|c|c|c|c|c|c|c|c|c|c|c|c|}
\hline \multirow{2}{*}{$\begin{array}{l}0 \\
0 \\
0 \\
0 \\
\frac{0}{0} \\
0 \\
0\end{array}$} & \multirow{2}{*}{$\begin{array}{l}\frac{\widehat{0}}{0} \\
\frac{0}{0} \\
\frac{0}{2} \\
\overline{0} \\
\vdots \\
\overline{0}\end{array}$} & \multirow{2}{*}{ 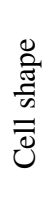 } & \multirow{2}{*}{ 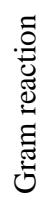 } & \multirow[b]{2}{*}{ 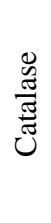 } & \multirow{2}{*}{ 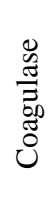 } & \multirow[b]{2}{*}{ 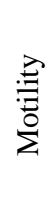 } & \multicolumn{6}{|c|}{ Sugar fermentation } & \multirow{2}{*}{ 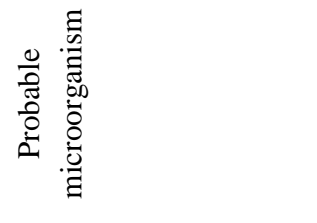 } \\
\hline & & & & & & & 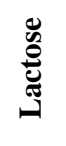 & 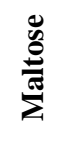 & 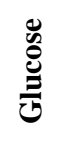 & 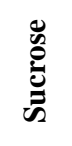 & 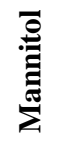 & $\frac{\ddot{o}}{\frac{\partial}{\lambda}}$ & \\
\hline B1 & TDFCR & $\mathrm{R}$ & - & + & - & - & AG & AG & AG & AG & AG & AG & Klebsiella oxytoca \\
\hline B2 & TMFS & $\mathrm{R}$ & + & - & - & - & NR & NR & NR & $\mathrm{AG}$ & $\mathrm{AG}$ & $\mathrm{AG}$ & Lactobacillus plantarum \\
\hline B3 & TMRIR & $\mathrm{C}$ & + & - & + & - & $\mathrm{AG}$ & $\mathrm{AG}$ & $\mathrm{AG}$ & $\mathrm{AG}$ & AG & $\mathrm{AG}$ & Lactococcus lactis \\
\hline B4 & TRIR & $\mathrm{R}$ & + & + & - & + & AG & AG & AG & AG & AG & AG & Citrobacter fruendii \\
\hline B5 & TCRIC & $\mathrm{R}$ & + & + & - & + & AG & AG & AG & AG & AG & AG & Bacillus subtilis \\
\hline
\end{tabular}

KEY: $(+)=$ positive,$(-)=$ negative, TDFCR $=$ Translucent, Dry, Flat, Circular, Rough. TMFS = Translucent, Milky, Flat, Smooth, TMRIR = Translucent, Milky, Raised, Irregular, Rough, TRIR= Translucent, Raised, Irregular, Rough, TCRI. Translucent, creamy, raised, irregular, $\mathrm{C}=$ Cocci, $\mathrm{R}=$ rod, $\mathrm{Y}=$ yam, $\mathrm{AG}=$ acid and gas production, $\mathrm{NR}=$ No reaction.

Table 3: Biochemical characteristics of yeasts isolated during fermentation

\begin{tabular}{|c|c|c|c|c|c|c|c|c|c|c|}
\hline$\frac{\mathscr{E}}{\stackrel{0}{0}}$ & 胥 & 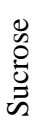 & $\begin{array}{l}0 \\
0 \\
0 \\
0 \\
0 \\
0\end{array}$ & 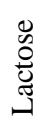 & 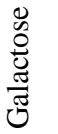 & $\begin{array}{l}0 \\
\stackrel{0}{0} \\
\stackrel{\Xi}{\Xi} \\
\Sigma\end{array}$ & $\frac{0}{\infty}$ & $\begin{array}{l}0 \\
0 \\
0 \\
0 \\
0 \\
0 \\
0\end{array}$ & 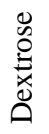 & 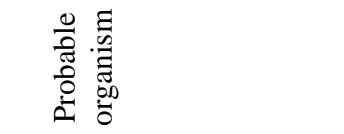 \\
\hline Y1 & + & + & + & + & + & + & - & + & - & Saccharomyces cerevisiae \\
\hline $\mathbf{Y} 2$ & + & - & + & - & - & + & - & - & - & Candida tropicalis \\
\hline
\end{tabular}

KEY : + = Positive, - = Negative

Table 4: Cultural and microscopic characteristics of fungal isolates from fermented yam steep

\begin{tabular}{|l|l|l|}
\hline Cultural characteristics & Microscopic characteristics & \multicolumn{1}{|c|}{ Probable fungi } \\
\hline $\begin{array}{l}\text { Light yellow base with black fluffy } \\
\text { mycelia growth and yellow reverse } \\
\text { colouration. }\end{array}$ & $\begin{array}{l}\text { Hypha is septate with upright } \\
\text { conidiophore and smooth cell. }\end{array}$ & Aspergillus niger \\
\hline $\begin{array}{l}\text { Glister cream rice-like colony. } \\
\text { Flat, smooth creamy colony. }\end{array}$ & $\begin{array}{l}\text { Gram positive, ovoid and round cluster. } \\
\text { true germ tubes. }\end{array}$ & Saccharomyces cerevisiae \\
\hline White cotton-like mycelia growth. & $\begin{array}{l}\text { Hypha is hyaline and septate, with short } \\
\text { conidiospores. }\end{array}$ & Fusarium oxysporum \\
\hline
\end{tabular}

Table 5: Occurrence of microorganisms from fermented yam tubers

\begin{tabular}{|l|c|c|c|}
\hline Isolate & \multicolumn{2}{|c|}{ Fermentation time (hours) } & $\mathbf{4 8}$ \\
\hline & $\mathbf{0}$ & $\mathbf{2 4}$ & - \\
\hline Klebsiella oxytoxa & + & + & + \\
\hline Lactobacillus plantarum & + & + & + \\
\hline Lactococcus lactis & + & + & - \\
\hline Citrobacter fruendii & + & + & + \\
\hline Bacillus subtilis & - & - & - \\
\hline Aspergillus niger & - & - & + \\
\hline Fusarium oxysporum & - & + & + \\
\hline Candida tropicalis & - & + & + \\
\hline Saccharomyces cerevisiae & - & + & + \\
\hline
\end{tabular}

KEY: + = present, $-=$ absent 
Ojokoh et al., Int. Ann. Sci.; Vol. 8, Issue 1, pp: 87-95, 2020

\section{3 pH, Total Titratable Acidity and Temperature Values}

Table 6 shows the $\mathrm{pH}$, total titratable acidity and temperature of fermenting yam tubers. The $\mathrm{pH}$ of the fermenting sample decreased from 6.4 to 4.9 while the total titratable acidity and temperature increased from 0.16 to $4.24 \%$ and $28^{\circ} \mathrm{C}$ to $34^{\circ} \mathrm{C}$ respectively.

Table 6: $p H$, total titratable acidity and temperature values

\begin{tabular}{|c|c|c|c|}
\hline $\begin{array}{c}\text { Time } \\
\text { (hours) }\end{array}$ & $\mathrm{pH}$ & TTA (\%) & $\begin{array}{c}\text { Temperature } \\
\left({ }^{\circ} \mathrm{C}\right)\end{array}$ \\
\hline 0 & $6.42^{\mathrm{b}}$ & $0.16^{\mathrm{a}}$ & $28^{\mathrm{a}}$ \\
\hline 24 & $5.41^{\mathrm{a}}$ & $2.57^{\mathrm{b}}$ & $30^{\mathrm{b}}$ \\
\hline 48 & $5.02^{\mathrm{a}}$ & $3.46^{\mathrm{c}}$ & $31^{\mathrm{b}}$ \\
\hline 72 & $4.91^{\mathrm{a}}$ & $4.24^{\mathrm{d}}$ & $34^{\mathrm{c}}$ \\
\hline
\end{tabular}

Values are means of triplicate determinations. Values with the same superscript down the column are not significantly different $(\mathrm{p}<0.05)$.

\subsection{Proximate Composition of Fermented and Unfermented Yam Flour}

The results of proximate composition of the samples were shown in Table 7. The moisture $(12.32 \%)$ and carbohydrate contents $(82.76 \%)$ and of the fermented sample were significantly $(p<0.05)$ higher when compared with unfermented sample with moisture and carbohydrate contents $10.57 \%$ and $80.66 \%$ respectively.

Table 7: Proximate composition of fermented and unfermented yam flour

\begin{tabular}{|l|l|l|}
\hline $\begin{array}{l}\text { Proximate Composition } \\
(\%)\end{array}$ & $\begin{array}{l}\text { Fermented } \\
\text { Sample }\end{array}$ & $\begin{array}{l}\text { Unfermented } \\
\text { Sample }\end{array}$ \\
\hline Moisture content & $12.321 \pm 0.13^{\mathrm{a}}$ & $10.567 \pm 0.13^{\mathrm{b}}$ \\
\hline Ash content & $0.704 \pm 0.01^{\mathrm{a}}$ & $1.581 \pm 0.03^{\mathrm{a}}$ \\
\hline Fat content & $0.187 \pm 0.04^{\mathrm{a}}$ & $0.432 \pm 0.09^{\mathrm{a}}$ \\
\hline Crude protein content & $2.463 \pm 0.10^{\mathrm{a}}$ & $1.513 \pm 0.012^{\mathrm{b}}$ \\
\hline Crude fibre content & $3.571 \pm 0.30^{\mathrm{a}}$ & $3.244 \pm 0.03^{\mathrm{a}}$ \\
\hline Carbohydrate content & $82.755 \pm 0.03^{\mathrm{a}}$ & $80.664 \pm 0.20^{\mathrm{b}}$ \\
\hline
\end{tabular}

Data are represented as mean \pm standard deviation $(n=3)$ with the same superscript across the row are not significantly different $(\mathrm{p}<0.05)$.

Similar trend was observed in the protein content $2.46 \%$ of the fermented sample when compared with unfermented sample with protein content $1.51 \%$. The ash content of the fermented sample was $0.70 \%$. There was no significant different in the fat, crude fibre and carbohydrates contents of the samples.

\subsection{Anti-nutrients Composition of Fermented and Unfermented Yam Tubers}

Table 8 shows the antinutrients composition of fermented and unfermented yam tubers. The antinutrients content of the unfermented sample were significantly higher than the fermented sample. The phytate and saponin contents with higher values in the samples decreased from 11.12 to $5.77 \mathrm{mg} / \mathrm{kg}$ and 31.29 to $11.45 \mathrm{mg} / \mathrm{kg}$ respectively. There was no significant different in the oxalate and the alkaloids contents of the samples.

Table 8: Anti-nutrients composition of fermented and unfermented yam tubers

\begin{tabular}{|l|l|l|}
\hline $\begin{array}{l}\text { Anti-nutrients } \\
\text { Composition }\end{array}$ & Fermented Sample & $\begin{array}{l}\text { Unfermented } \\
\text { Sample }\end{array}$ \\
\hline Phytate & $5.77 \pm 0.01^{\mathrm{a}}$ & $11.12 \pm 0.60^{\mathrm{b}}$ \\
\hline Oxalate & $0.32 \pm 0.06^{\mathrm{a}}$ & $0.90 \pm 0.04^{\mathrm{a}}$ \\
\hline Saponin & $11.45 \pm 0.25^{\mathrm{a}}$ & $31.29 \pm 0.02^{\mathrm{b}}$ \\
\hline $\begin{array}{l}\text { Alkaloids } \\
\text { Data are represented as mean } \pm \text { standard deviation }(\mathrm{n}=3) \text { with the } \\
\text { same superscript across the row are not significantly different } \\
(\mathrm{p}<0.05) .\end{array}$ \\
\hline \multicolumn{2}{|c|}{$0.04 \pm 0.20^{\mathrm{a}}$} \\
\hline
\end{tabular}

\subsection{Mineral Composition of Fermented and Unfermented Yam Tubers}

Table 9 shows the mineral composition of fermented and unfermented yam tubers. The mineral content of unfermented sample was significantly higher than the fermented sample. The potassium content of the fermented sample was $200 \mathrm{mg} / \mathrm{g}$ while unfermented sample had the highest value of $326 \mathrm{mg} / \mathrm{g}$. The zinc, iron and calcium of the fermented sample were $2.3 \mathrm{mg} / \mathrm{g}$, $2.5 \mathrm{mg} / \mathrm{g}$ and $10.21 \mathrm{mg} / \mathrm{g}$ with corresponding values of the unfermented sample (5.6, 4.1 and $97.55 \mathrm{mg} / \mathrm{g}$ ). For sodium and phosphorus, the fermented sample had the value $95.17 \mathrm{mg} / \mathrm{g}$ and $104.52 \mathrm{mg} / \mathrm{g}$ when compared with the unfermented sample with the value $101.04 \mathrm{mg} / \mathrm{g}$ and $149.16 \mathrm{mg} / \mathrm{g}$ respectively. 
Table 9: Mineral composition of fermented and unfermented yam tubers

\begin{tabular}{|l|l|l|}
\hline Minerals $(\mathrm{mg} / \mathrm{g})$ & Fermented sample & Unfermented sample \\
\hline Zinc & $2.3 \pm 0.04^{\mathrm{a}}$ & $5.6 \pm 0.11^{\mathrm{b}}$ \\
\hline Iron & $2.5 \pm 0.13^{\mathrm{a}}$ & $4.1 \pm 0.07^{\mathrm{b}}$ \\
\hline Calcium & $10.21 \pm 0.12^{\mathrm{a}}$ & $97.55 \pm 0.40^{\mathrm{a}}$ \\
\hline Sodium & $95.17 \pm 0.05^{\mathrm{a}}$ & $101.04 \pm 0.05^{\mathrm{b}}$ \\
\hline Potassium & $200.33 \pm 0.05^{\mathrm{a}}$ & $326.63 \pm 0.10^{\mathrm{b}}$ \\
\hline Phosphorus & $104.52 \pm 0.35^{\mathrm{a}}$ & $149.16 \pm 0.06^{\mathrm{b}}$ \\
\hline \multicolumn{2}{|l|}{ Data are represented as mean \pm standard deviation $(\mathrm{n}=3)$ with the same superscript across the row are not significantly different $(\mathrm{p}<0.05$} \\
\hline
\end{tabular}

Table 10: Sensory evaluation ( $g$ ) of the fermented and unfermented yam flour gruel (amala)

\begin{tabular}{|l|l|l|l|l|l|}
\hline Samples & Colour & Taste & Aroma & Texture & Overall acceptability \\
\hline Fermented yam gruel & $7.35 \pm 0.07^{\mathrm{a}}$ & $7.20 \pm 0.14^{\mathrm{a}}$ & $6.35 \pm 0.07^{\mathrm{a}}$ & $8.76 \pm 0.28^{\mathrm{a}}$ & $7.25 \pm 0.25^{\mathrm{a}}$ \\
\hline Unfermented yam gruel & $6.30 \pm 0.14^{\mathrm{a}}$ & $6.55 \pm 0.07^{\mathrm{a}}$ & $6.10 \pm 0.14^{\mathrm{a}}$ & $8.25 \pm 0.28^{\mathrm{a}}$ & $6.2 \pm 0.14^{\mathrm{a}}$ \\
\hline
\end{tabular}

\subsection{Sensory Evaluation of the Fermented and Unfermented Yam Flour Gruel (Amala)}

Table 10 shows the sensory evaluation of the fermented and unfermented yam flour gruel. The fermented sample showed general overall acceptability than the unfermented sample. There were significant different in the sensory parameters except the aroma. The rating of the colour, taste, texture and overall acceptability of the fermented and unfermented sample were $7.35 \mathrm{~g}, 7.20 \mathrm{~g}, 8.76 \mathrm{~g}, 7.25 \mathrm{~g}$ and $6.30 \mathrm{~g}, 6.55 \mathrm{~g}$, $8.25 \mathrm{~g}, 6.20 \mathrm{~g}$.

\section{Discussion}

In this study, different microorganisms were isolated from the fermented yam tubers. It was observed that the microbial loads increased throughput the fermentation period. The increase in microbial population might be due to their ability to utilize the available nutrient in the fermentation medium, favourable environmental condition and absence of growth inhibitors [12]. The occurrence of Staphylococcus aureus could be contaminant from the handlers, processing equipment's and the surrounding environment. The result corroborates the findings of Adegbehingbe et al [13] who reported isolation of Staphylococcus aureus while fermenting cassava tubers during fufu production. The lactic acid bacteria generally grow readily in most food substrates at low $\mathrm{pH}$, their ability to secrete organic acids (mostly lactic acid) inhibit the growth of pathogenic and spoilage microorganisms [14]. Lactic acid bacteria have been reported to release toxic substances such as hydrogen-peroxide, diacetyl, organic acids and bacteriocin into the fermenting medium during fermentation process [15]. The survival of Bacillus subtilis could probably due to their ability to form spores and withstand unfavourable harsh conditions. Isolation of different microorganisms from fermented foods have been reported [13, 16, 17].

Decrease in $\mathrm{pH}$ with corresponding high in the total titratable acidity was observed during the fermentation process. These phenomena may have been as a result of the metabolic activities of the microorganisms capable of hydrolysing complex organic compounds and production of organic acids such as citric, lactic acid and butyric acid into the medium that lower the $\mathrm{pH}$. The growth of lactic acid bacteria is favoured at low $\mathrm{pH}$, causing inhibition to other microorganisms that are not desirable during the fermentation most especially the food borne pathogens [18]. The production of organic acids during food fermentation has been attributed to the activities of the lactic acid bacteria on the carbohydrates of food substrates [19]. The increase observed in the temperature of the fermented sample might be due to the metabolic activities of the fermenting microorganisms which lead to the generation of 
heat as a result of exothermic reactions mediated by microbial enzymes during the fermentation [20]. Mesophilic temperature ranges observed during fermentation was responsible for the survival of acid producing microorganisms which support their growth and secretion of extracellular enzymes during fermentation [21].

Fibre form bulk of roughage that aid human digestion, softens stools and lowers plasma cholesterol level in the body [19]. The crude fibre of the fermented sample showed a significant increase $(p<0.05)$ when compared to the unfermented sample. Low fibre content in food could help in lowering the cholesterol level; relieve constipation and prevention of colon cancer [14]. Also, the observed increase in fibre content may be attributed to the high total dietary fibre content found in the yam tuber. High fibre content in diets have been reported to result in increased removal of potential mutagens, steroids and xenobotics by binding or absorbing to dietary fibre components and there by aids digestion [22]. The crude fibre content $0.73 \%$ (unfermented cocoyam flour) and $0.19 \%$ (fermented cocoyam flour) at 72 hours has been reported [23]. The increase in the carbohydrate content might be due to the utilization of some of the sugars by the fermenting microorganisms as carbon source, apparent increase in protein content and decrease in the moisture content of the sample.

The protein content of the fermented yam tubers increase as fermentation time progresses. This trend could be attributed to the increase in microbial biomass and secretion of extracellular enzymes (protease), causing hydrolysis of protein molecules to amino acids, peptides and other simple nitrogenous compounds in the fermentation medium and enzymatic hydrolysis of some protein inhibitors during fermentation [24]. The variation observed in the protein content of the samples may be attributed the specie of yam used and the other environmental conditions where yam was grown. Igbabul et al. [23] had reported an increase in protein content of fermented cocoyam from 15.61 to $18.75 \%$. Increase in protein content of fermented cocoyam from 4.93 - 5.17 has also been reported [25].

Ash content is a measure of the total amount of minerals present within a food. The reduction in the ash content of the fermenting substrates could be as a result of the minerals being used up by the fermenting microorganisms for their metabolic activities [26]. Also the decrease in ash content can be ascribed to possible leaching of soluble mineral elements into fermenting medium or due to general activities of the fermenting microorganisms whose enzymatic activity resulted in breakdown of food components into their absorbable forms [9]. High ash content observed from the unfermented sample could suggest high mineral in the sample than the fermented sample. The results obtained corroborate the findings of Igbabul et al. [23] while fermenting cocoyam flour. The low fat content level observed in the fermented sample might be due to the lipolytic activity of the fermenting microorganisms capable of hydrolysing fats and oils to fatty acids and glycerol, contributing to the sensory improvement such as aroma, taste, odour and texture of the sample during fermentation. The increase in fat might be from fermenting microflora capable of secreting microbial oils [27]. Availability of water in most foods contributes to the growth and survival of microorganisms. High water content in food easily caused food deterioration and rapid spoilage. The decrease in the moisture content of the sample could be attributed to the drying method adopted which reduce the moisture level preventing the growth of spoilage microorganisms while the increase in the moisture content of the fermented sample might be due to the addition of water and the release of free bond water in the fermentation medium [28].

Saponin is an antinutritional factor with foaming characteristics in aqueous solution, hemolytic activity and cholesterol binding properties and bitterness. Saponin contains natural antibiotics which help the body to fight infections and microbial invasion. The significant reduction in the anti-nutrient composition of fermented yam tubers could be due to the leaching of its contents into fermenting water and the activities of microorganisms [20]. The reduction in phytate content may be attributed to the activities of endogenous phytase enzyme from raw ingredient and inherent microorganisms which are capable of hydrolysing the phytic acid in the fermented food preparations into inositol and orthophosphate 
[29]. The decrease observed in the oxalates and saponnin levels of the fermented sample might be due to the activities of fermenting microorganisms and the processing methods. The result obtained was in agreement with the findings of Igbabul et al. [23] who reported a decrease in the oxalate content of fermented cocoyam flour from 0.95 0.01. Bello et al. [29] have reported the presence of alkaloids, flavonoids, saponins, lectin, trypsin inhibitors, phytate and oxalate in the African yam. The alkaloid (2.77\%), flavonoid (1.38\%), saponin $(2.71 \%)$, tannin $(0.21 \%)$ and phenol (1.91\%) contents of raw water yam (Discorea alata) have also been reported [30]. The residual phyate content of the fermented yam flour falls within the FAO recommended safe level making the yam flour safe for both human and animal consumption. The presence of alkaloids in the tubers of $D$. alata indicates that yam tubers cannot be eaten raw by human. Most alkaloids are known for their pharmacological effects rather than their toxicity which could cause gastro-intestinal upset and neurological disorders [9].

The significant increase recorded for potassium, calcium and sodium in the unfermented sample agrees with the report of Oyarekua [16] while fermenting bitter yam and cowpea. The sensory properties of foods greatly contribute to their acceptability in determining the choice for consumers need. The fermented sample was rated moderately accepted and overall acceptability when compared with the unfermented sample with slight or less acceptability. The overall acceptability of the samples could be due to the metabolic activities of microorganisms initiating the fermentation process and large surface area of yam flour after milling [31]. The result obtained from the textural parameters agrees with the findings of Offiah et al. [32] who reported 8.30 (like very much) while fermenting malted fermented maize and African yam bean-based tortilla. Similarly, the general overall acceptability of amala produced from water yam-cassava flour has also been reported [33].

\section{Conclusion}

The resultant low moisture and high carbohydrate contents obtained from the samples could reduce the drying time, long storage and preservation, safety, extend shelf life, preventing the growth of pathogenic and spoilage microorganisms and as excellent energy food for man. However, the decrease in the antinutritional contents and the pronounced sensory parameters of the fermented samples could make it more acceptable and marketable to the consumers.

\section{Declarations}

\subsection{Acknowledgements}

The authors appreciate the staff in the Department of Microbiology, Federal University of Technology, Akure, Nigeria, for their technical assistance.

\subsection{Competing interests}

The authors declared no potential conflict of interest exists.

\section{How to Cite this Article:}

A. Ojokoh and B. Adeleke, "Processing of Yam Paste (Amala): A Product of Fermented Yam (Dioscorea rotundata) Flour", Int. Ann. Sci., vol. 8, no. 1, pp. 87-95, Oct. 2019. doi: 10.21467/ias.8.1.87-95

\section{References}

[1] C. Tortoe, S. Dowuona, P. T. Akonor, N. T. Dziedzoave. Examining the physicochemical, functional and rheological properties in flours of farmers' 7 key yams (Dioscorea spp.) varieties in Ghana to enhance yam production. Cogent Food and Agriculture, vol. 3, pp. 1371564. 2017.

[2] C. Omohimi, C. Piccirillo, V. Ferraro, M. C. Roriz, M. A. Omemu, S. M. D. Santos, S. Ressurreição, L. Abayomi, A. Adebowale, M. W. Vasconcelos, O. Obadina, L. Sanni, M. M. E. Pintado. Safety of yam-derived (Dioscorea rotundata) foodstuffs-chips, flakes and flour: Effect of processing and post-processing conditions. Foods, vol. 8, pp. 1-19. 2019.

[3] V. Ferraro, C. Piccirillo, K. Tomlins, M. E. Pintado. Cassava (Manihot esculenta Crantz) and yam (Dioscorea spp.) crops and their derived foodstuff: Safety, security and nutritional value. Critical Review Food Science and Nutrition. vol. 56, pp. 2714-2727. 2016.

[4] B. Djeri, P. F. Tchobo, Y. Adjrah,Y. Ameyapoh, M. M. Soumanou, C. Souza. Nutritional potential of yam chips (Dioscorea cayenensis and Dioscorea rotundata Poir) obtained using two methods of production in Togo. African Journal of Food Science, vol. 9, no. 5, pp. 278284. 2015.

[5] C. Omohimi, C. Piccirillo, M. Roriz, V. Ferraro, W. M. Vasconcelos, L. O. Sanni, M .M. Pintado, L. A. Abayomi. Study of the proximate and mineral composition of different Nigerian yam chips, flakes and flours. Journal of Food Science and Technology, vol. 55, pp. 42-51. 2017.

[6] E. E. Bassey, U. S. Akpan. Evaluation of guinea white yam for yield and yield components in Nigeria. American Journal of Experimental Agriculture, vol. 8, no. 4, pp. 216-223. 2015

[7] I. L. Princewill-Ogbonna, C. C. Ibeji. Comparative study on nutritional and anti-nutritional composition of three cultivars (red, green and yellow) of aerial yam (Dioscorea 
Ojokoh et al., Int. Ann. Sci.; Vol. 8, Issue 1, pp: 87-95, 2020

bulbifera). Journal of Environmental Science, Toxicology and Food Technology, vol. 9, no. 5, pp. 79-86. 2015.

[8] B. O. Otegbayo, D. J. Oguniyan, B. A. Olunlade, O. O. Oroniran O. E. Atobatele. Characterizing genotypic variation in biochemical composition, anti-nutritional and mineral bioavailability of some Nigerian yam (Dioscorea spp.) land races. Journal of Food Science and Technology, vol. 55, no. 1, pp. 205-216. 2018.

[9] A. S. Ajala, T. O. Idowu. Investigation on the quality of fermented white yam flour (elubo) at different drying temperatures. Canadian Journal of Agricultureand Crops, vol. 1, no. 1, pp. 1-10. 2016.

[10] I. M. Ogara, A. B. Zarafi, O. Alabi, O. Banwo, C. N. Ezekiel, B. Warth, M. Sulyok, R. Krska. Mycotoxins patterns in ear rot infected maize: A comprehensive case study in Nigeria. Food Control, vol. 73, pp. 1159-1168. 2017.

[11] AOAC (2012).Official methods of analysis 18th Edition. Washington, DC. U.S.A. pp. 191-195.

[12] A. I. Augustine, E. O. Airaodion, O. Ewa, E. O. Ogbuagu, U. Ogbuagu. Nutritional and anti-nutritional evaluation of garri processed by traditional and instant mechanical methods. Asian Food Science Journal, vol. 9, 4, pp. 1-13. 2019.

[13] K. T. Adegbehingbe, S. Fakoya, O. M. Bello, B. S. Adeleke, O. S. Fagbohun, D. O. Adejoro. Antibacterial properties of the predominant microorganisms isolated from fermenting cassava tubers during fufu production against selected enteropathogenic bacteria. European Journal of Nutrition \& Food Safety, vol. 9, no. 3, pp. 287296. 2019.

[14] B. S. Adeleke, O. O. Olaniyi. Starter culture development from lactic acid bacteria for improved nutritive value of linamarase treated cassava peels. Journal of Biomaterials, vol. 2, no. 1, pp. 1-6. 2018.

[15] A. O. Ojokoh, O. O. Adaja, A. O. Omojokun. Effect of fermentation on the nutritional composition of Roselle calyx obtained from Ekiti and Benue State, Nigeria. Journal of Advances in Microbiology, vol. 11, no. 4, pp. 1-7. 2018.

[16] M. A. Oyarekua. Effect of co-fermentation on nutritional and sensory evaluation of bitter yam and cowpea as complementary food. International Journal of Current Microbiology and Applied Sciences, vol. 5, no. 4, pp. 267278. 2016.

[17] O. O. Olaniyi, B. S. Adeleke, B. J. Akinyele, O. A Ibitoye. Microbiological and antibiotic susceptibility pattern of bacteria associated with burukutu - a nonalcoholic beverage. Journal of Food Resource Science, vol. 7, pp. 1-7. 2018.

[18] D. V. Adegunloye, T. C. Oparinde. Effect of fermentation on the proximate composition of Irish (Solanium tuberosum) and Sweet potato (Ipomoea babatas) peels. Advances in Microbiology, vol. 7, pp. 565-574, 2017.

[19] A. O. Ojokoh, O. E. Fayemi, F. C. K. Ocloo, F. I. Nwokolo. Effect of fermentation on proximate composition, physicochemical and microbial characteristics of pearl millet (Pennisetum glaucum (L.) R. Br.) and acha (Digitaria exilis (Kippist) Stapf) flour blends. Journal of Agricultural Biotechnology and Sustainable Development, vol. 7, no. 1, pp. 1-8, 2015.

[20] G. F. Hassan, L. Yusuf, T. T. Adebolu, A. K. Onifade. Effect of fermentation on minerals and anti-nutritional composition of cocoyam (Colocasia esculenta linn). Sky Journal of Food Science, vol. 4, no. 4, pp. 42-49. 2015.

[21] F. Ayoade, P. O. Adeniji, K. S. Amole, Y. A. Amaremo, T. O. Apata, S. O. Fayemi, N. O. Oyejide, U. D. Abazuh, T. A. Kayode, G. G. Daramola, O. Folarin. The predominant lactic acid microorganisms and proximate composition of spontaneously fermented gari and fufu, cassava food products. Annual Research and Review in Biology, vol. 26, no. 2, pp. 1-12. 2018.

[22] A. O. Ojokoh, R. A. O. Gabriel. A comparative study on the storage of yam chips (gbodo) and yam flour (elubo).
African Journal of Biotechnology, vol. 9, no. 2, pp. 31753177. 2010.

[23] B. D. Igbabul, J. Amove, I. Twadue. Effect of fermentation on the proximate composition, antinutritional factors and functional properties of cocoyam (Colocasia esculenta) flour. African Journal of Food Science and Technology, vol. 5, no. 3, pp. 67-74. 2014.

[24] G. Oboh, C. Elusiyan. Changes in the nutrient and antinutrietn content of micro-fungi fermented cassava flour produced from low-and-medium-cynaide variety of cassava tubers. African Journal of Biotechnology, vol. 6, pp. 2150-2157, 2007.

[25] G. O. Ogunlakin, M. O. Oke, G. O. Babarinde, D. G. Olatunbosun. Effect of drying methods on proximate composition and phytochemical properties of cocoyam flour. American Journal of Food Technology, vol. 7, pp. 245-250. 2012.

[26] O. T. Adepoju, O. Boyejo, P. Adeniji. Nutrition and antinutrient composition of yellow yam products. Data in Brief, vol. 11: pp. 428-431. 2017.

[27] J. O. Nwafor, V. C. C. Ezeocha, A. C. Kanu, O. D. Onyebula. Food processing characteristics of water yam (Dioscorea alata) and cowpea (Vigna unguiculata) flour blend used locally for production of concessionaries. Universal Journal of Agricultural Research, vol. 7, no. 3, pp. 125-130. 2019.

[28] K. T. Adegbehingbe, S. Fakoya, B. S. Adeleke. Nutritional and antinutritional contents of fermented whole and ground african breadfruit (Treculia africana) seeds. Microbiology Research Journal International vol. 20, no. 5, pp. 1-11. 2017.

[29] B. K. Bello, A. O. Ojokoh, S. E. Ojokoh. Mineral and antinutritional composition of fermented water yam (Dioscorea alata). International Journal of Life Sciences and Technology, vol. 5, no. 3, pp. 20-23. 2017.

[30] V. C. Ezeocha, P. C. Ojimelukwe. The impact of cooking on the proximate composition and antinutritional factors of water yam (Discorea alata). Journal of Stored Products and Postharvest Research, vol. 3, no. 13, pp. 172-176. 2012.

[31] A. O. Ojokoh, A. O. Fagbemi. Effects of fermentation and extrusion on the proximate and organoleptic properties of cowpea-plantain flour blends. British Microbiology Research Journal, vol. 13, no. 4, pp. 1-13. 2016.

[32] L. O. Offiah, C. C. Ariahu, M. A. Igyor. Effect of malting and fermentation on the proximate composition and sensory properties of maize (Zea mays) and African yambean (Sphenosylis stenocarpa) - based tortilla. The International Journal of Engineering and Science, vol. 5, no. 8, pp. 01-06. 2016. www.theijes.cpm/ISSN (P): 2319180.

[33] J. M. Babajide, S. Olowe. Chemical, functional and sensory properties of water yam-cassava flour and its paste. International Food Research Journal, vol. 20, no. 2, pp. 903-909. 2013.

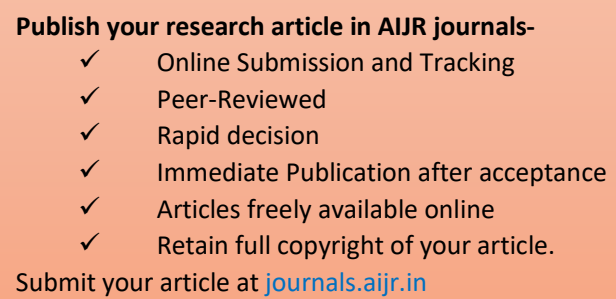

Submit your article at journals.aijr.in 